\title{
Placental Mesenchymal Stromal Cells (PMSCs) and PMSC-Derived Extracellular Vesicles (PMSC-EVs) Attenuated Renal Fibrosis in Rats with Unilateral Ureteral Obstruction (UUO) by Regulating $\mathrm{CD4}^{+} \mathrm{T}$ Cell Polarization
}

\author{
Zhu Zhu, Chaonan Han, Shuli Xian, Feng Zhuang, Feng Ding, Wei Zhang $\mathbb{D}$, \\ and Yingli Liu
}

Department of Nephrology, Shanghai Ninth People's Hospital, Shanghai Jiao Tong University School of Medicine, Shanghai 200011, China

Correspondence should be addressed to Wei Zhang; 18621657463@126.com and Yingli Liu; 18616375719@163.com

Received 28 September 2019; Revised 22 April 2020; Accepted 9 June 2020; Published 22 July 2020

Academic Editor: Valeria Sorrenti

Copyright $\odot 2020$ Zhu Zhu et al. This is an open access article distributed under the Creative Commons Attribution License, which permits unrestricted use, distribution, and reproduction in any medium, provided the original work is properly cited.

\begin{abstract}
Purpose. Recent evidence has shown that $\mathrm{CD}^{+} \mathrm{T}$ helper (Th) cells are involved in renal inflammation and fibrosis. However, whether renal fibrosis can be alleviated by intervening in the polarization of $\mathrm{CD}^{+} \mathrm{T}$ cells remains unknown. Our research investigated the effects of intravenously administered placenta mesenchymal stromal cells (PMSCs) or treatment with extracellular EVs (EVs) derived from PMSCs (PMSC-EVs) on the polarization of $\mathrm{CD}^{+} \mathrm{T}$ cells in rats with unilateral ureteral obstruction (UUO). We further verified how PMSCs affect inflammatory factor secretion and the levels of regulatory T (Treg) and Th17 $\mathrm{CD}^{+} \mathrm{T}$ cells in vitro. Materials and Methods. We evaluated renal interstitial inflammation and fibrosis by pathological section staining, tested the polarization of $\mathrm{CD}^{+} \mathrm{T}$ cells (Th17 and Treg phenotypes) by flow cytometry (FCM) and immunohistochemistry, and detected the cytokines secreted by $\mathrm{CD} 4^{+} \mathrm{T}$ cells by enzyme-linked immunosorbent assay (ELISA). Results. Compared with that of control rats, the renal tissue of PMSC-treated rats exhibited lower renal Masson scores and more Foxp $3^{+}$cell infiltration, with a significantly decreased IL17 $\mathrm{A}^{+} \mathrm{CD} 4^{+} \mathrm{T}$ cell/CD $4^{+} \mathrm{T}$ cell ratio and a significantly elevated antiinflammatory cytokine (IL-10) level. When $\mathrm{CD}^{+} \mathrm{T}$ cells were cocultured with PMSCs, $\mathrm{CD}^{+}{ }^{+} \mathrm{IL} 17 \mathrm{~A}^{+}$cell percentages were decreased in a UUO model after 7 days of coculture with PMSCs. The secretion of TGF- $\beta$ and IL-10 was significantly increased $(P<0.05)$, while the secretion of IFN- $\gamma$, IL-17, and IL-6 was significantly decreased $(P<0.05)$ in the PMSC coculture group. Moreover, after treatment with PMSC-EVs, tubulointerstitial fibrosis was alleviated, and Foxp $3^{+} / \mathrm{IL}-17^{+}$cell infiltration was increased in the kidneys of UUO model animals on day 7. Conclusions. PMSCs can convert the inflammatory environment into an anti-inflammatory environment by affecting the polarization of $\mathrm{CD} 4^{+} \mathrm{T}$ cells and macrophages, inhibiting the inflammatory factors IFN- $\gamma$ and IL-17, and upregulating the expression of the anti-inflammatory factors TGF- $\beta$ and IL-10, ultimately leading to renal protection. Such functions may be mediated by the paracrine activity of PMSC-EVs.
\end{abstract}

\section{Introduction}

Unilateral ureteral obstruction- (UUO-) induced subacute renal injury is characterized by tubular cell injury, interstitial inflammation, and renal fibrosis. Recent studies indicated that intervening in the polarization of $\mathrm{CD}^{+} \mathrm{T}$ cells could be a potential therapeutic approach to prevent excessive fibrosis and loss of renal function due to injury [1-3]. Based on their cytokine secretion profiles and the expression of specific transcription factors, $\mathrm{CD} 4^{+} \mathrm{T}$ cells are classified into four major subpopulations: T helper (Th) 1, Th2, Th17, and regulatory $\mathrm{T}$ (Treg) cells, and additional Th cell lineages might exist. IFN- $\gamma$ is known to induce Th1 cell production, and interleukin (IL)-17 increases $\mathrm{CD} 4^{+} \mathrm{T}$ cell proliferation that differentiates naïve $\mathrm{CD} 4^{+} \mathrm{T}$ cells into Th17 cells, which are considered proinflammatory $\mathrm{T}$ cells. Treg cells and IL- 
4-induced Th2 cells are identified as anti-inflammatory subsets [4-6]. These studies indicate that the polarization of immune cells is vital to maintaining homeostasis and inflammatory processes.

Mesenchymal stromal cells (MSCs) are multipotent stromal cells characterized by their abilities to differentiate into cells that compose mesodermal tissue and inhibit the proliferation of $\mathrm{T}$ and B lymphocytes, natural killer cells, and dendritic cells both in vitro and in vivo, making them an effective stromal cell source for regenerative medicine [7]. Nevertheless, the application of MSCs derived from the bone marrow (BM-MSCs) has essential limitations, including the invasive harvest procedure and limited accessibility due to the low cell yield $[8,9]$.

Our previous study found that BM-MSCs transformed an inflammatory environment into an anti-inflammatory environment to induce immune tolerance by inhibiting the inflammatory factor IFN- $\gamma$, upregulating the expression of the anti-inflammatory factor IL-10, and regulating the Treg cell population and function [10]. In this study, we isolated MSCs from the placenta (PMSCs); this procedure was simple and did not involve any invasive processes. By transplanting PMSCs into UUO rats, PMSCs were shown to effectively alleviate kidney inflammation by interfering with $\mathrm{CD} 4{ }^{+} \mathrm{T}$ cell polarization. To investigate the underlying mechanism, we further verified how PMSCs affect the secretion of inflammatory factors by $\mathrm{CD} 4^{+} \mathrm{T}$ cells in vitro. However, none of the tested molecules were sufficient to fully account for the function of PMSCs.

MSC-derived extracellular vesicles (EVs) are 100 to $200 \mathrm{~nm}$ endosome-derived vesicles [11] and are enriched for a subset of diverse protein and mRNA cargo [12], indicating that they are relatively likely to work as a whole. Many data have also shown that MSC-derived EVs are immunologically active and can induce Treg cells in vitro and in vivo [13]. In this study, we performed further in vivo investigations to explore whether PMSC-EVs can relieve fibrosis and influence the anti-inflammatory switch by modulating the balance of Treg/Th17 cells in renal tissue after UUO.

\section{Materials and Methods}

2.1. Animal Modeling and Experimental Methods. Specific pathogen-free (SPF) Sprague-Dawley (SD) rats (male, 8 weeks) and pregnant SD rats (14-16 days) were purchased from the Shanghai Laboratory Animal Research Center. All animals were kept in Shanghai Ninth's Hospital of the Shanghai Laboratory Animal Center. This study was approved by the local ethics committee. All experiments were performed in accordance with the National Institutes of Health Guide for the Care and Use of Laboratory Animals.

Rats were randomly divided into sham and UUO groups, with 18 animals in each group. Operations were performed by exposing the right kidney through a flank incision and then immediately closing the incision (sham) or ligating the ureter immediately distal of the renal pelvis (UUO model) [10]. For in vivo experiments, UUO rats were randomly divided into groups receiving PMSCs intervention $\left(2 \times 10^{5}\right.$ cells) or saline injection as a control via postcava injection at the start of UUO. The rats were sacrificed 3, 7, or 14 days after surgery.
2.2. Isolation and Culture of Placenta-Derived Primary Cells. The placenta of SD rats was collected on gestational days 14 to 16 , rinsed with sterile PBS [14], cut into small pieces, digested with trypsin and collagenase 6 for 45 mins at $37^{\circ} \mathrm{C}$, and then filtered with a $200 \mu \mathrm{m}$ mesh sieve. After centrifugation at $1,500 \mathrm{rpm}$, the cells were resuspended in low-glucose DMEM (LG-DMEM) supplemented with $10 \%$ heat-inactivated fetal bovine serum. They were then cultured at a density of $4 \times 10^{5} /$ $\mathrm{ml}$ at $37^{\circ} \mathrm{C}$ in a $5 \% \mathrm{CO}_{2}$ atmosphere. The cells were cultured to $80 \%$ confluency, and FACS analysis was performed using a FACSCalibur (BD, USA).

2.3. Isolation and Characterization of PMSC-EVs. EVs were prepared from the supernatant of PMSC cultures with serum-free LG-DMEM. Briefly, the conditioned medium was collected at $48 \mathrm{~h}$. In total, $170 \mathrm{ml}$ supernatant was processed through $0.45 \mu \mathrm{m}$ and $0.22 \mu \mathrm{m}$ filters to remove intact cells and debris. Then, Amicon ultracentrifugal filters (Millipore Sigma, Darmstadt, Germany) were used to concentrate the cell supernatant into $1 \mathrm{ml}$ as a unit dose, and an equal volume of ExoQuick was added and incubated overnight at $4^{\circ} \mathrm{C}$. EVs were isolated with a 30-minute low-speed spin (1500g). The purified EVs were stored at $-80^{\circ} \mathrm{C}$ until use. The expression of the EV markers HSP70, TSG101, CD81, CD9, and CD63 (rabbit monoclonal antibodies (mAbs), Cell Signaling Technology, USA) was detected using Western blotting. The purified EVs were further identified with a nanoparticle tracking analysis (NTA) system and transmission electron microscopy.

2.4. Assessment of the Degree of Tubular Injury Using Masson Staining. Paraffin renal tissue sections were stained with Masson's trichrome. A quantitative evaluation based on arbitrary scores was performed by a blinded observer for the indicated histopathological parameters. We evaluated 10 fields (400x) in each pathological section of renal interstitial tissue stained with Masson's trichrome and considered bright blue collagen deposition as a positive signal. Image ProPlus software was used for analysis, and the ratio of the interstitial collagen deposition area to the area without deposition was calculated and averaged.

2.5. Immunohistochemical and Immunofluorescence Staining. After deparaffinization, renal sections were treated with 3\% $\mathrm{H}_{2} \mathrm{O}_{2}$ for $10 \mathrm{~min}$ to inactivate endogenous peroxidases. The sections were blocked with 5\% normal rabbit serum and then incubated with primary antibodies specific for $\alpha$-SMA ( $1: 100$, Abcam), collagen I (1:500, Abcam), FoxP3 (1:100, Abcam), IL17 ( $1: 100$, Abcam), and CD4 (1:50, Abcam) overnight at $4^{\circ} \mathrm{C}$, followed by incubation with secondary antibodies for $60 \mathrm{~min}$. After being washed three times, the tissue sections were visualized by the dropwise addition of peroxidaselabeled streptavidin-biotin (SABC) and 3,3N-diaminobenzidine tetrahydrochloride (DAB) (Dako Corporation).

2.6. $\mathrm{CD}^{+} \mathrm{T}$ Cell Isolation. $\mathrm{CD}^{+} \mathrm{T}$ lymphocytes were obtained from the peripheral blood (PB) of rats and used to establish in vitro groups. Red blood cells were eliminated by density gradient centrifugation, and $\mathrm{CD}^{+} \mathrm{T}$ cells were purified (>90\%) from the mononuclear cells using $\mathrm{CD}^{+} \mathrm{T}$ 
cell Isolation Kit MicroBeads (Miltenyi Biotec, Bergisch Gladbach, Germany) according to the manufacturer's instructions.

2.7. PMSCs and $C D 4^{+} T$ Cells Coculture Evaluation. The effect of the addition of PMSCs to $\mathrm{CD} 4^{+} \mathrm{T}$ cell cultures was tested by coculturing cells at a ratio of $10: 1 \mathrm{CD}^{+} \mathrm{T}$ cells vs. PMSCs. To activate $\mathrm{CD} 4^{+} \mathrm{T}$ cells, purified $\mathrm{CD} 4^{+} \mathrm{T}$ cells were seeded in anti-CD3 $\mathrm{Ab}(5 \mu \mathrm{g} / \mathrm{ml}, \mathrm{BD}$ Biosciences) and anti-CD28 Ab-coated plates $(10 \mu \mathrm{g} / \mathrm{ml}, \mathrm{BD}$ Biosciences), and treated with IL-2 (10 ng/ml, R\&D Systems, USA) for 3 days $[15,16]$. Then, a transwell system (Corning, $0.4 \mu \mathrm{m}$ pore size) was utilized for PMSCs and $\mathrm{CD}^{+} \mathrm{T}$ cells coculture. Activated $\mathrm{CD}^{+} \mathrm{T}$ cells were seeded in the lower chamber while PMSCs were seeded in the upper chamber. After 72 hours incubation, $\mathrm{CD} 4^{+} \mathrm{T}$ cells were stained with $\mathrm{CD} 25$ APC/Foxp3-FITC or IL17-APC/CD4-PE and analyzed by FCM analysis, respectively. Manufacturer instructions were followed for all procedures.

2.8. Flow Cytometry (FCM) Analysis. Rats were sacrificed by cervical dislocation, and the kidneys and spleen were removed under aseptic conditions. Peripheral heparinized blood was collected from the rats. The kidney tissue was digested with collagenase IV for $60 \mathrm{~min}$ at $37^{\circ} \mathrm{C}$, while the spleen was ground with an injector. They were filtered with a $200 \mu \mathrm{m}$ mesh sieve, and then single cells were collected and suspended in RPMI 1640 medium. Splenocytes were plated in 24-well plates at a concentration of $1 \times 10^{6} / \mathrm{ml}$, and phorbol 12-myristate 13-acetate (PMA), ionomycin, and monensin were added at the concentrations $500 \mathrm{ng} / \mathrm{ml}$, $1 \mu \mathrm{g} / \mathrm{ml}$, and $1 \mathrm{mM}$, respectively (all from Calbiochem, San Diego, CA); the cells were then incubated at $37^{\circ} \mathrm{C}$ in $5 \%$ $\mathrm{CO}_{2}$ for $4 \mathrm{~h}$. Red blood cell lysis buffer ( $4 \mathrm{ml} /$ tube) was then added and incubated for $10 \mathrm{~min}$. After washing, fluorophorelabeled anti-CD4 or anti-CD25 Abs (eBioscience, USA) or an isotype control $\mathrm{Ab}$ was added for surface staining for $30 \mathrm{~min}$ at room temperature (RT) in the dark, followed by two washes with PBS containing $0.1 \%$ bovine serum albumin (BSA). Foxp3 staining procedures were performed according to the manufacturer's instructions. Intracellular staining of T cells was performed after $6 \mathrm{~h}$ of activation with PMA $(1 \mathrm{ng} / \mathrm{ml})$ and ionomycin $(1 \mathrm{mg} / \mathrm{ml})$. Then, the cells underwent surface staining with the fluorochrome-conjugated anti-CD4 Ab. An anti-rat IL-17A PE-conjugated Ab $(2 \mu \mathrm{l})$ in $100 \mu \mathrm{l}$ staining buffer was added to the cell pellet after centrifugation and incubated at $4^{\circ} \mathrm{C}$ for $30 \mathrm{~min}$ in the dark. Flow cytometry analysis of cytokine production was performed using an anti-IL-17 allophycocyanin-conjugated $\mathrm{mAb}$.

PMSCs were incubated for $20 \mathrm{~min}$ at $4^{\circ} \mathrm{C}$ with combinations of the following Abs conjugated to fluorescein isothiocyanate (FITC) or Phycoerythrin (PE): anti-CD45 (BioLegend), anti-CD90 (eBioscience), anti-CD34 (BioLegend), anti-CD105 (eBioscience), anti-HLA (BioLegend), and anti-CD29 (eBioscience).

2.9. ELISA Analysis of Cytokine Production. Serum was collected from rat $\mathrm{PB}$, and the supernatant of a renal cortex homogenate generated from right kidney tissue pestled in a homogenizer was also collected. In vitro, each well of a cul- ture plate suspension was centrifuged, and the cells in the pellet were collected. The supernatant was used for enzyme-linked immunosorbent assay (ELISA) (eBioscience) analysis of inflammatory factors.

\section{Results}

3.1. Characterization of PMSCs and PMSC-EVs. PMSCs from pregnant rats were successfully isolated by adherence separation and reached $80-90 \%$ confluence by day 14 with a stable "fibroblast-like" spindle morphology. The MSC profile was confirmed based on positivity for the MSC-related markers CD29, CD90, and CD105 in the absence of positive for the hematopoietic marker CD45 CD34 and HLA, and the profile was evaluated by flow cytometry (Figure 1(a)). As indicated by our previous research, PMSCs are able to differentiate into adipocytes, chondrocytes, and osteoblasts under the appropriate culture conditions [10].

EVs were extracted from PMSCs, purified, and identified by morphology and EV marker expression An electron micrograph of phosphotungstic acid-stained EVs is shown (Figure 1(b)). The particle size and concentration of EVs were measured with an NTA system, with particle size peaking at $110 \mathrm{~nm}$ diameter (Figure 1(b)). Purified PMSC-EVs expressed EV marker proteins such as HSP70, TSG101, CD81, CD9, and CD63 (Figure 1(c)).

\subsection{PMSCs Attenuate Renal Interstitial Fibrosis in a UUO} Model. Masson's trichrome staining demonstrated that collagen accumulation in the interstitium progressively increased in the UUO group, and there was a significant reduction in the fibrotic area in the MSC-treated group $(P<0.05$; Figure 2(a) and 2(b)). Masson staining quantification showed that fibrosis was significantly reduced in the PMSC-treated group compared with the 3 -day $(P<0.05)$ and 14 -day UUO groups $(P<0.01)$.

3.3. PMSCs Intravenous Transplantation Promoted Treg Cell Infiltration into Obstructed Kidneys. Immunohistochemical staining (Figure $3(\mathrm{a})$ ) showed that Foxp $3^{+}$positive lymphocytes were mainly located in the foci of tubulointerstitial cells. After the UUO model establishment, renal interstitial infiltration of Foxp $3^{+}$Treg cells was significantly higher in the PMSC intervention group than in the other groups on day 14. Flow cytometry analysis indicated that the $\mathrm{PB} C D 4^{+-}$ $\mathrm{CD} 25^{+}$Treg/CD4 ${ }^{+}$cell ratios in the PMSC intervention group and saline injection group were significantly higher than the ratio in the sham group $(P<0.05)$. Moreover, there was no statistically significant difference between the PMSC intervention group and the saline injection group $(P>0.05)$ (Figure 3(b)).

Flow cytometry results also showed that in the rat spleen at 7 and 14 days after UUO model establishment, the percentage of IFN $\mathrm{IL}^{-} 17^{+} \mathrm{CD} 4^{+} \mathrm{T}$ cells in the $\mathrm{CD} 4^{+} \mathrm{T}$ cell population in the UUO group was significantly higher than that in the sham group $(P<0.05$, Figure $3(b))$. However, there was no statistically significant difference between the saline injection and PMSC intervention groups 3 days after UUO modeling $(P>0.05$, Figure $3(b))$. 

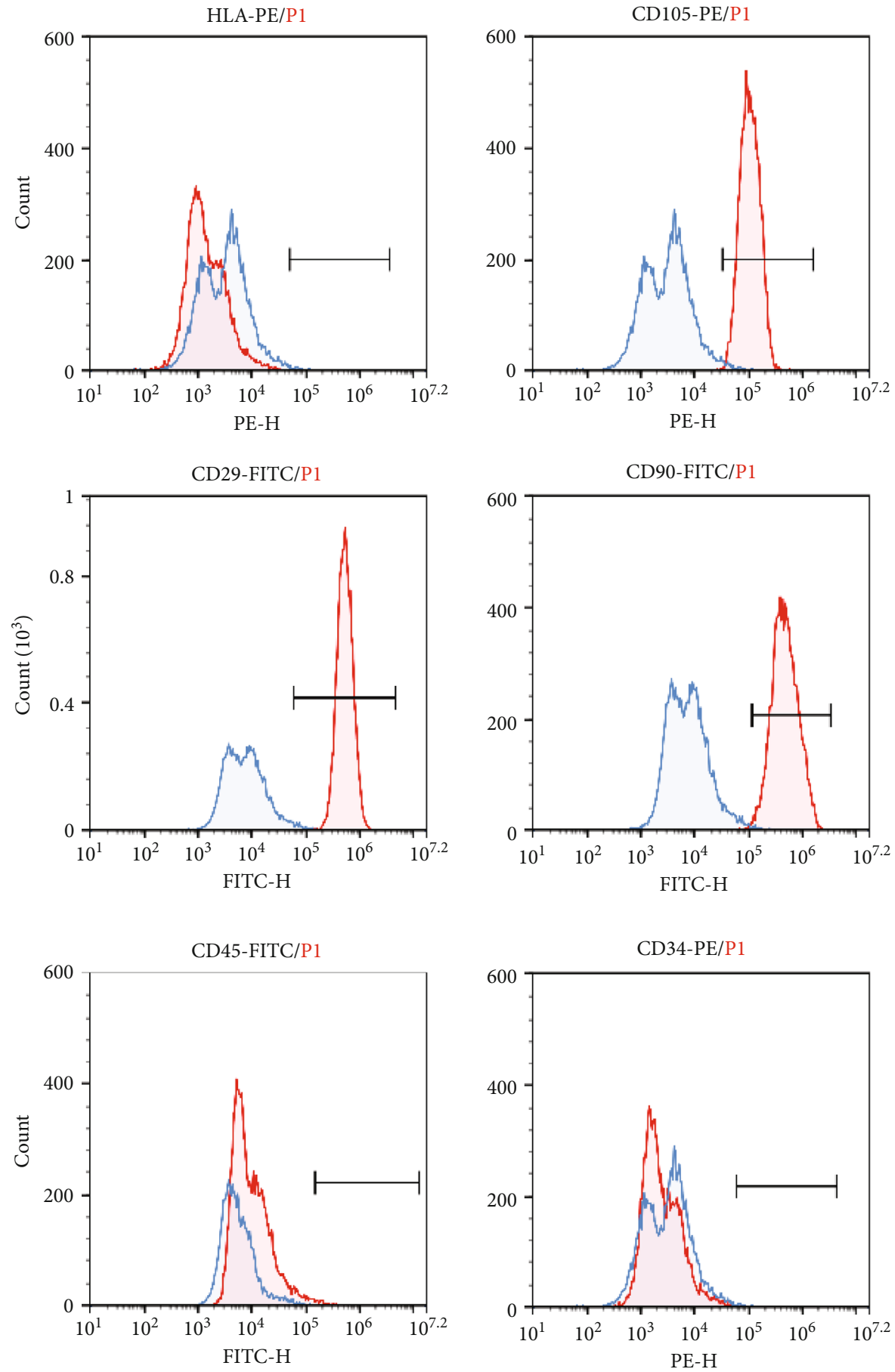

(a)

Figure 1: Continued. 

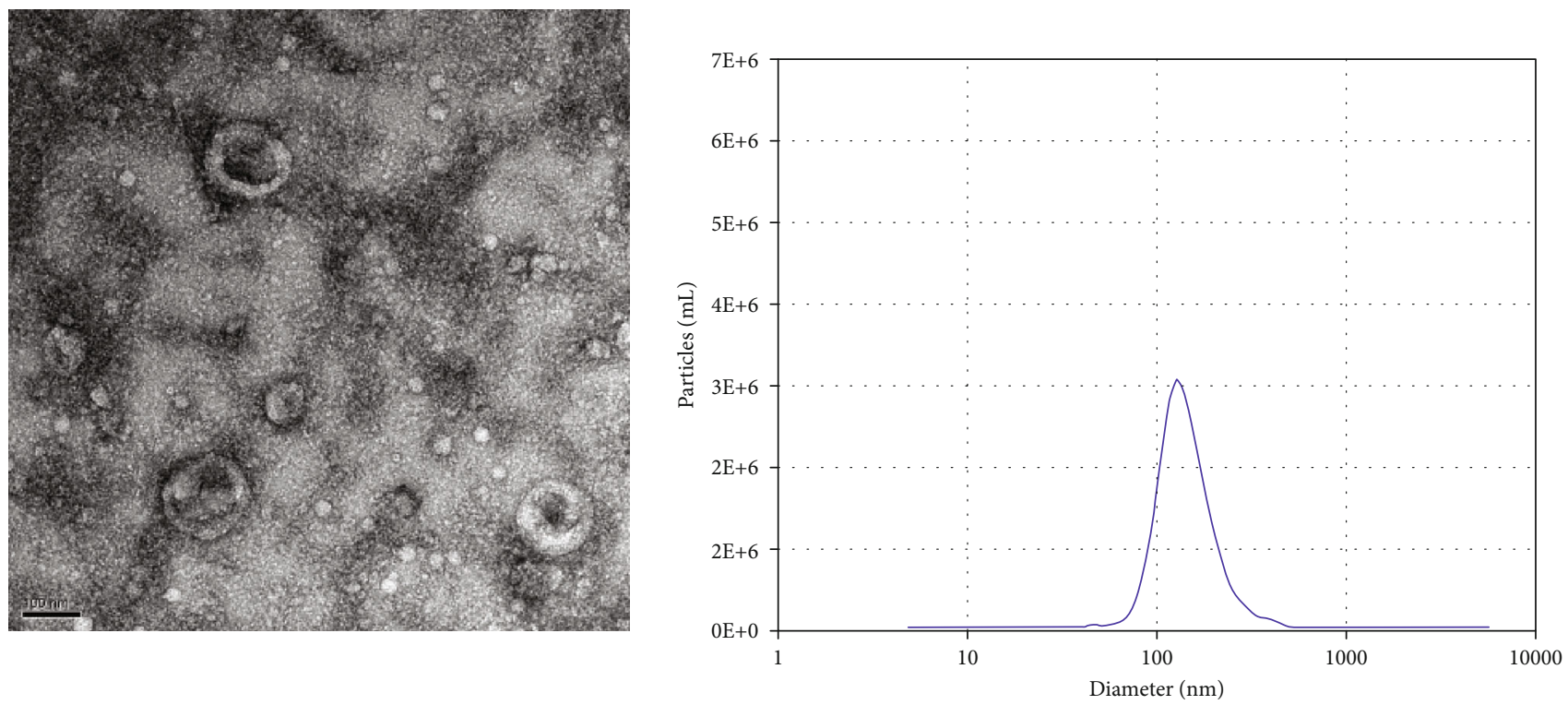

(b)

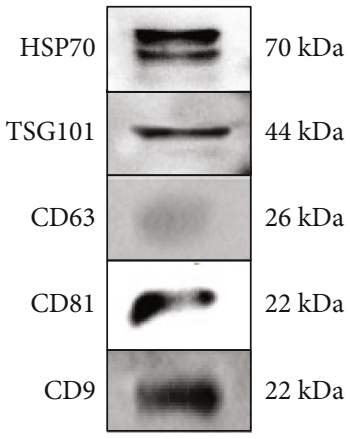

(c)

FIgure 1: Characterization of PMSC and PMSC EVs. (a) PMSC phenotypes were tested by flow cytometry. PMSCs were trypsinized and stained with MSC-related markers CD29, CD90, and CD105 and hematopoietic markers CD45, CD34, and HLA. (b) PMSC-EVs were extracted from cell supernatant. Representative micrograph of purified PMSC-EVs under transmission electron microscopy showing a cup-shaped membrane vesicle 30-100 nm in diameter (30,000×). Purified PMSC EVs particles have a diameter of $100 \mathrm{~nm}$. (c). Expression levels of typical molecular markers of EVs were tested by Western blot including HSP70, TSG101, CD63, CD81, and CD9.

3.4. PMSCs Affect the Treg/Th17 Cell Balance among Total $\mathrm{CD}^{+} \mathrm{T}$ Cells In Vitro. To further analyze the effect of PMSCs on the profiles of $\mathrm{CD} 4^{+} \mathrm{T}$ cells, we evaluated the Treg/Th17 cell balance among total $\mathrm{CD}^{+} \mathrm{T}$ cells with or without the addition of PMSCs after 3 days of activation. With PMSC coculture, the production of Treg cells and IL-17 by CD4 ${ }^{+}$ $\mathrm{T}$ cells cultured under baseline stimulation remarkably promoted $\mathrm{CD} 4^{+} \mathrm{T}$ proliferation and differentiation (Figure 4(a)). Furthermore, in these cultures, the addition of PMSCs markedly suppressed the expansion of Th17 cells 3 days after UUO modeling $(P<0.05$; Figures $4(\mathrm{~b})$ and $4(\mathrm{c}))$ and upregulated the level of $\mathrm{CD}^{+} \mathrm{CD} 25^{+} \mathrm{FOXP}^{+}$Treg cells at 7 days after UUO modeling $(P<0.05)$ (Figures $4(\mathrm{~b})$ and $4(\mathrm{c}))$.

3.5. Influence of PMSCs on Inflammatory Cytokine Production by $\mathrm{CD}^{+} \mathrm{T}$ Cells through a Paracrine Effect. We analyzed the effects of PMSCs on the profiles of $\mathrm{CD} 4^{+} \mathrm{T}$ cells both in vivo and in vitro. We detected the levels of the proinflammatory cytokines IFN- $\gamma$, IL- 6 , and IL-17, and we also tested the expression of the anti-inflammatory cytokines IL-4 and IL10. In the in vivo experiment, we found that the levels of IFN- $\gamma$ were significantly increased but the expression of IL-4, IL-6, and IL-10 was decreased significantly on days 3 and 7 in the UUO group compared with the sham operation group. IL-10 was the only cytokine upregulated in response to PMSC intervention on the $14^{\text {th }}$ day after UUO modeling $(P<0.05)$ (Figure 5(a)). For other cytokines, no significant differences were observed between the PMSC treatment group and the saline injection group $(P>0.05)$.

In in vitro experiments, we tested cytokines in each group culture plate suspension. Our data showed that the levels of IFN- $\gamma$ were significantly decreased when $\mathrm{CD} 4^{+} \mathrm{T}$ cells were cocultured with PMSCs on both day 3 and day 7 after UUO modeling $(P<0.05)$. The expression of IL- 6 decreased on day 3 , and that of IL-17 decreased on day 7 in the PMSC coculture group $(P<0.05)$. The levels of TGF- $\beta$ and IL-10 

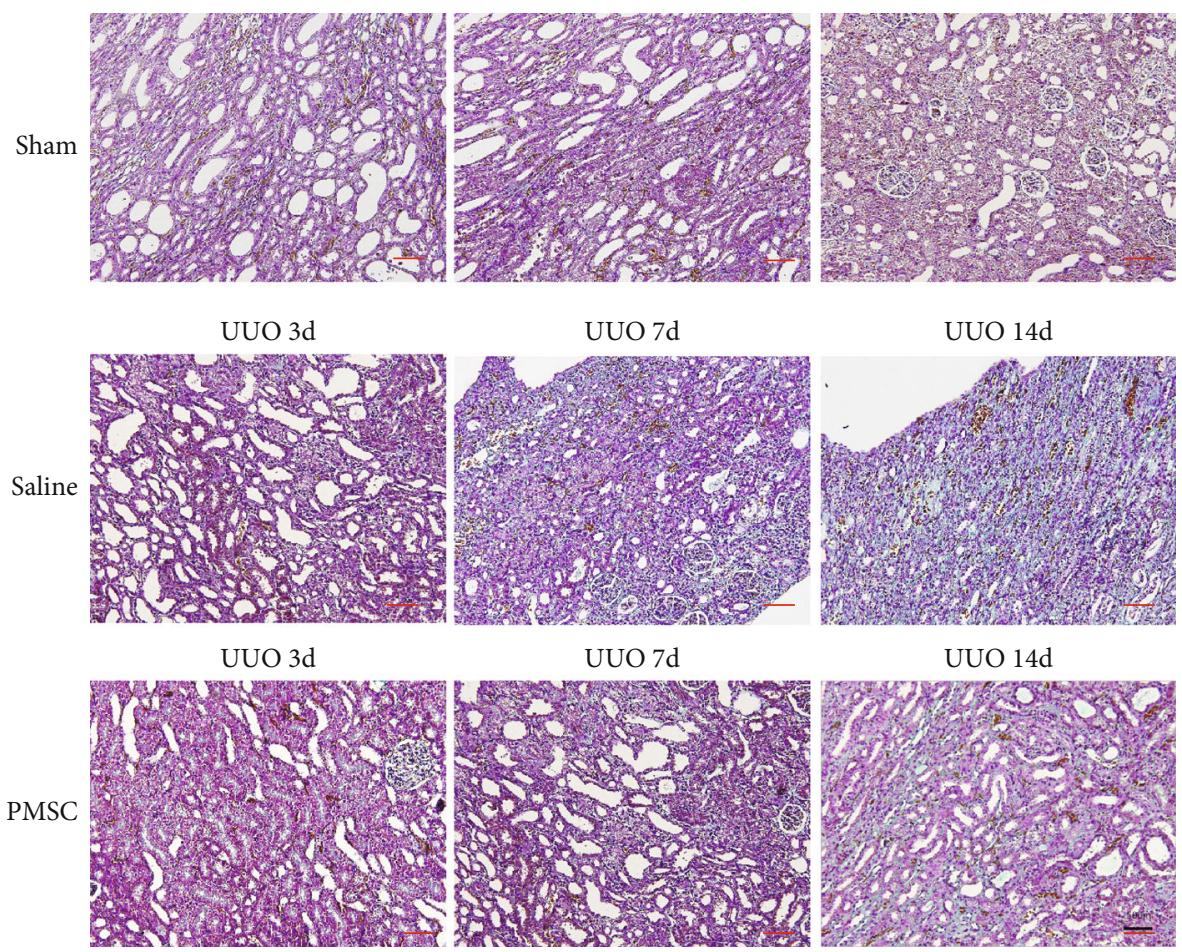

(a)

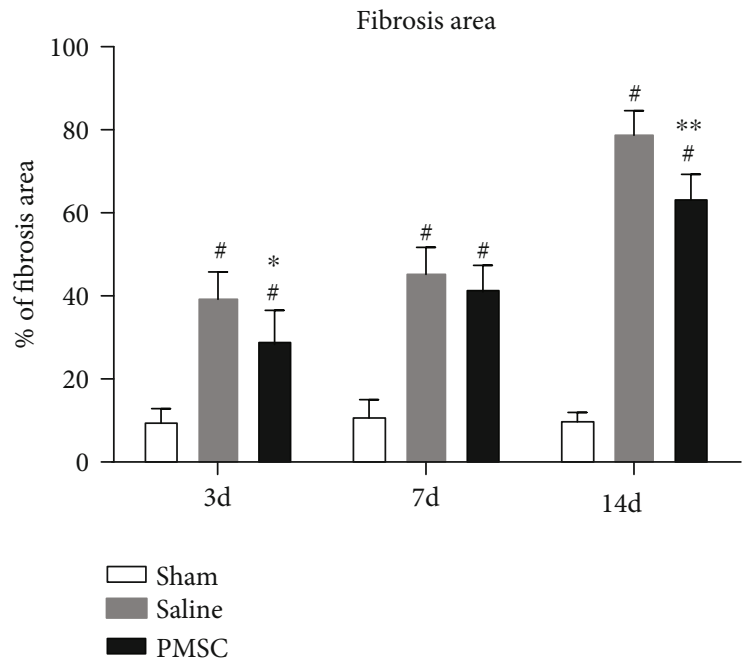

(b)

FIGURE 2: PMSCs regulate the UUO rat renal tubulointerstitial fibrosis. (a) Masson's trichrome staining of kidney sections from normal, saline, and PMSCs treated rats at day 3, 7, and 14 after UUO. Sham group $(n=5)$ represents the kidney from untreated rats after 3, 7, and 14 days, respectively. Saline group $(n=5)$ represents saline-treated kidney subjected to UUO after 3,7 , and 14 days, respectively. PMSC group $(n=5)$ represents PMSCs treated kidney at 3, 7, and 14 days, respectively. Scale bar: $50 \mu \mathrm{m}$. (b) Tubulointerstitial infiltration was quantified by image analysis using NIS Elements (Nikon). ${ }^{*} P<0.05$ compared with Saline group; ${ }^{* *} P<0.01$ compared with Saline group; ${ }^{\#} P<0.05$ compared with Sham group.

were significantly increased in the PMSC coculture group on both day 3 and day $7(P<0.05)$. There were no significant differences in IL-4 expression between the PMSC coculture group and the $\mathrm{CD} 4^{+} \mathrm{T}$ cell group (Figure $5(\mathrm{~b})$ ).

3.6. PMSC-EVs Alleviate Renal Tubulointerstitial Fibrosis and Affect Foxp3+/IL-17 $7^{+}$Cell Infiltration into the Kidneys of UUO Rats on Day 7. EV-treated rats showed less collagen deposition in the renal interstitium than untreated rats, as quantified by $\alpha$-SMA staining and immunohistochemical staining (Figures 6(a) and 6(c)). In addition, the number of $\mathrm{CD}^{+} \mathrm{T}$ cells infiltrating the affected kidneys was reduced in the EV-treated group compared with the untreated group (Figures 6(b)-6(e)). 

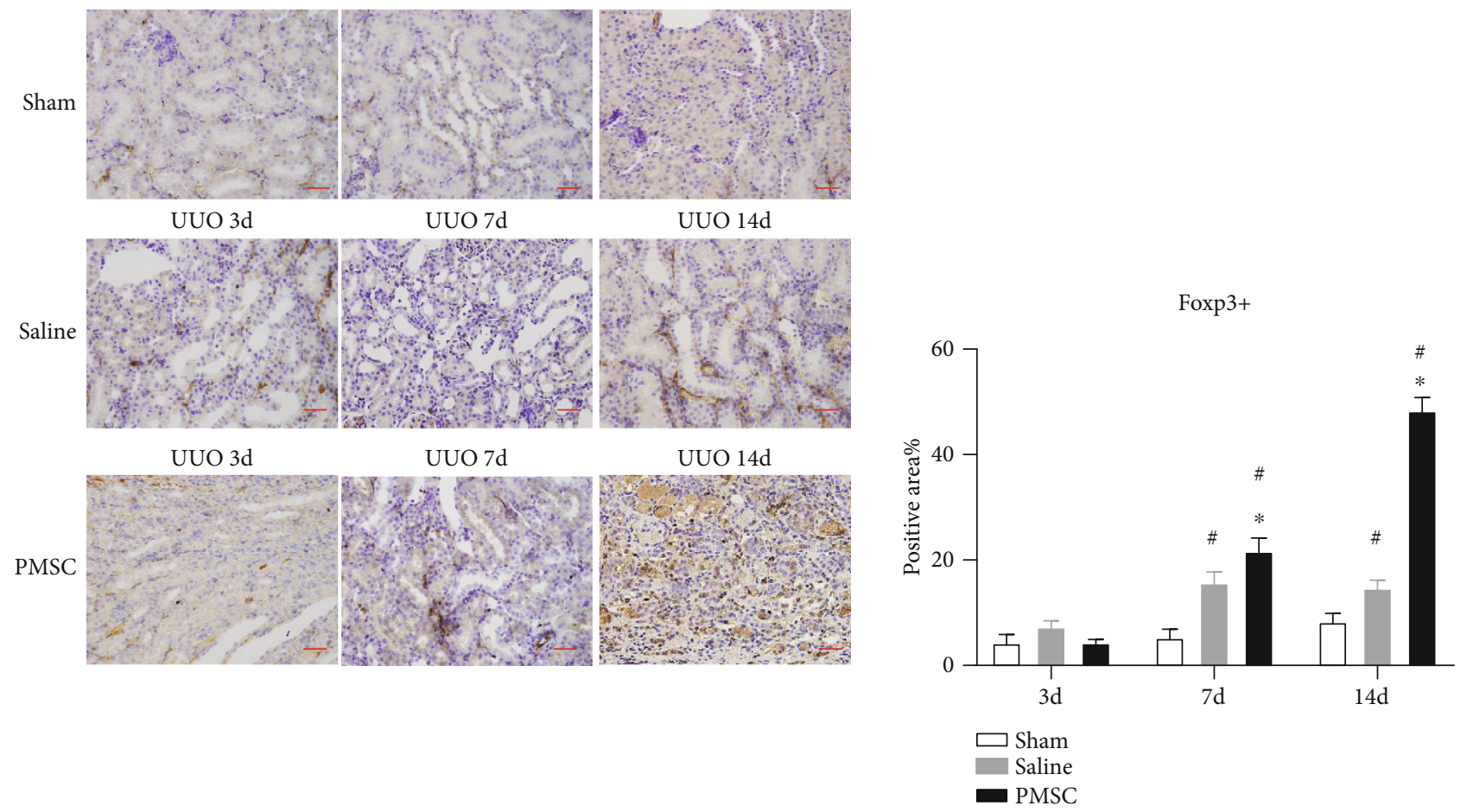

(a)
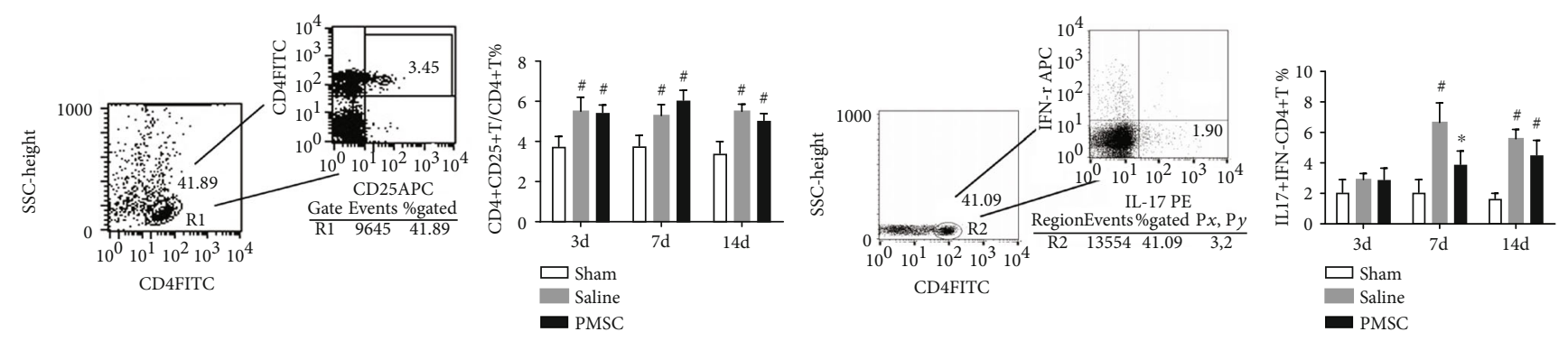

(b)

FIgURE 3: Effects of PMSCs injection on regulating CD4 ${ }^{+} \mathrm{CD} 25^{+}$Foxp3 T cells and $\mathrm{IL}_{17} \mathrm{IFN}^{-} \mathrm{T}$ cells of UUO rats in vivo. (a) IHC staining of Foxp3 in kidney sections from Sham, Saline, and PMSC group at days 3, 7, and 14 after UUO, respectively. Representative pictures are acquired. Scale bar: $50 \mu \mathrm{m}$. Foxp3 positive percentage was quantitated by measuring positive area from representative images and analyzed by image J software. ${ }^{*} P<0.05$ compared with Saline group; ${ }^{*} P<0.01$ compared with Saline group; ${ }^{\#} P<0.05$ compared with Sham group. (b) The percentage of $\mathrm{CD}^{+} \mathrm{CD} 25^{+} \mathrm{T}$ cells in $\mathrm{CD} 4^{+} \mathrm{T}$ cells extracted from PMNCs as well as the percentage of IL- $17^{+} \mathrm{IFN}^{-} \gamma \mathrm{T}$ cell in $\mathrm{CD} 4^{+}$ T cells extracted from rat spleen homogenate was analyzed by FACs, respectively. ${ }^{\#}$ indicates $P<0.05 \mathrm{VS}$. sham. ${ }^{*} P<0.05$ compared with Saline group; ${ }^{*} P<0.05$ compared with Sham group.

\section{Discussion}

In the UUO model, interstitial inflammatory cell infiltration progressively increased from $12 \mathrm{~h}$ after obstruction through up to 14 days. The infiltrated leukocytes were mainly macrophages and T lymphocytes. The role of T lymphocytes in the progression of renal fibrosis was significantly highlighted. Depletion of $\mathrm{CD}^{+} \mathrm{T}$ cells in wild-type mice with a mAb significantly reduced the amount of interstitial expansion and collagen deposition after 2 weeks of obstruction [17]. CD4 ${ }^{+}$ $\mathrm{T}$ cells can differentiate into three subpopulations, the Th1, Th2, and Th17 subsets [18]. The pivotal role of Th2 cells versus the classic role of Th1 cells was recently highlighted, and the Th17 response was also enhanced in the UUO model [19-21]. These studies indicated that renal interstitial injury could be improved by interfering with the polarization of $\mathrm{CD} 4^{+} \mathrm{T}$ cells.

In previous research, the effectiveness of bone marrow stem cell (BMSC) therapy on UUO rats was apparent, and we found that BMSCs could quantifiably ameliorate fibrosis. In this study, there was no significant relief in fibrosis after PMSC treatment. This may be related to the insufficient quantities of stromal cells, and some of these cells were damaged by phagocytosis in the pulmonary vascular system.

Moreover, we found that the ratio of $\mathrm{CD} 4^{+} \mathrm{CD} 25^{+} \mathrm{T}$ cells to $\mathrm{CD} 4^{+} \mathrm{T}$ cells in the $\mathrm{PB}$ and the ratio of IL17A ${ }^{+} \mathrm{IFN} \gamma^{-} \mathrm{CD} 4^{+}$ $\mathrm{T}$ cells to $\mathrm{CD} 4^{+} \mathrm{T}$ cells in the spleen were significantly higher in the UUO group than in the control group. These results suggest that Treg and Th17 cells are involved in the processes of renal interstitial inflammation and fibrosis. In addition, 


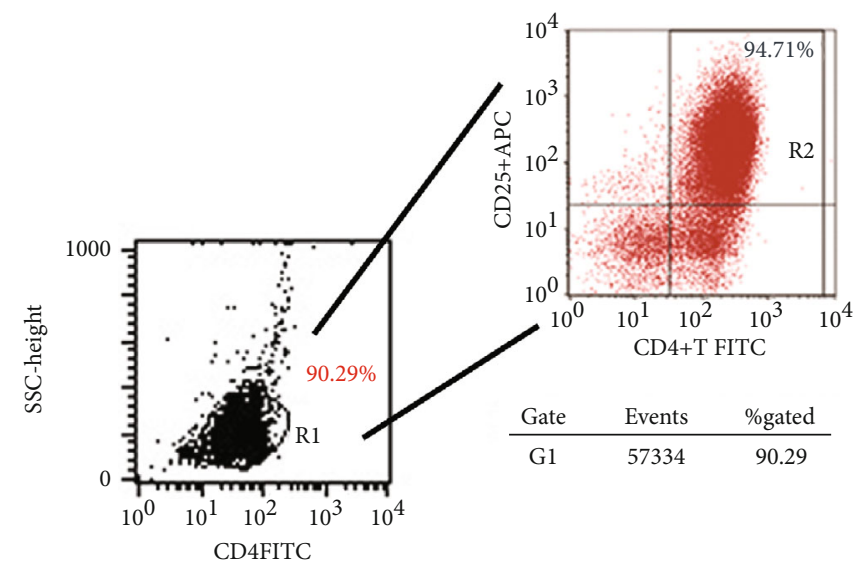

(a)

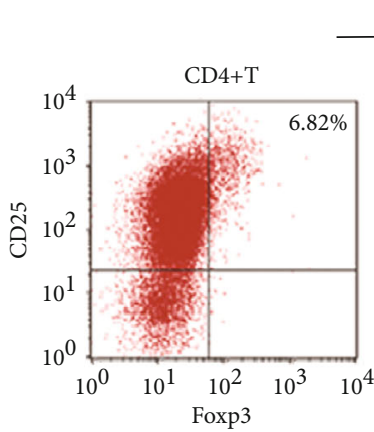

UUO 3d
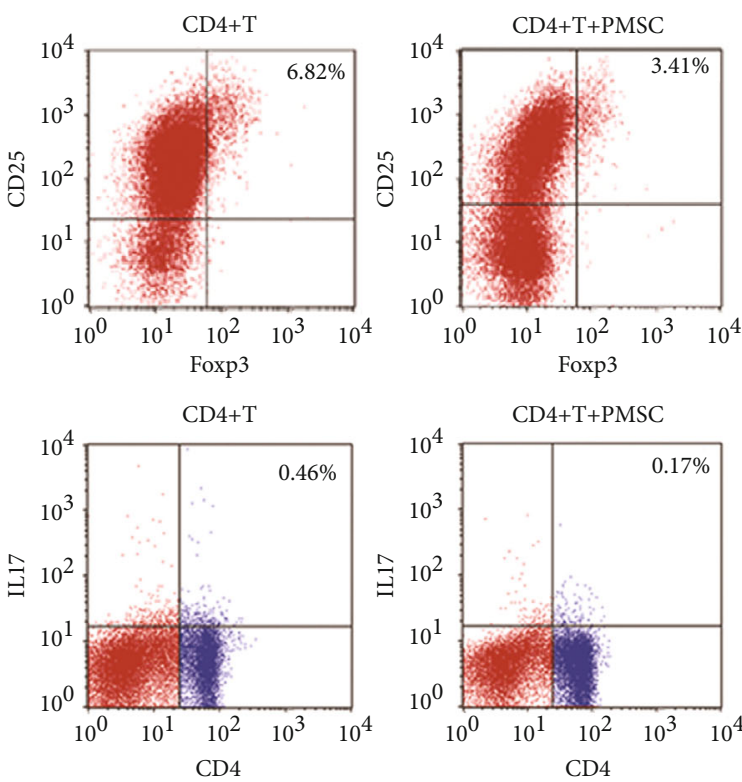

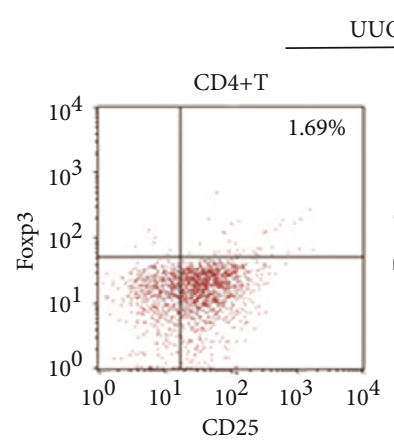

UUO 7d
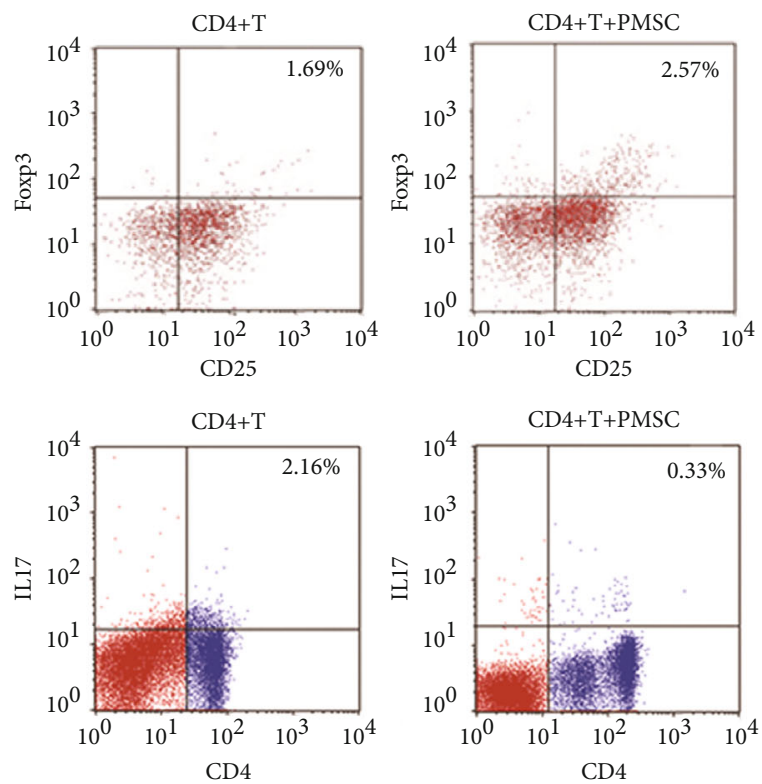

(b)

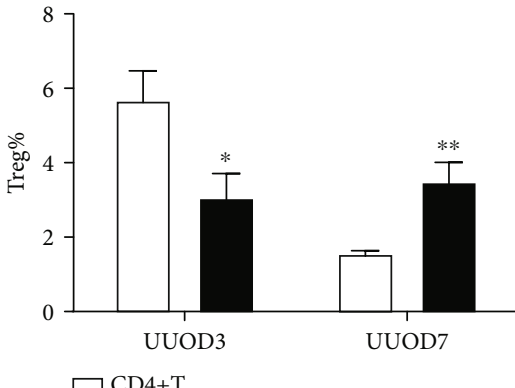

- $\mathrm{CD} 4+\mathrm{T}+\mathrm{PMSC}$

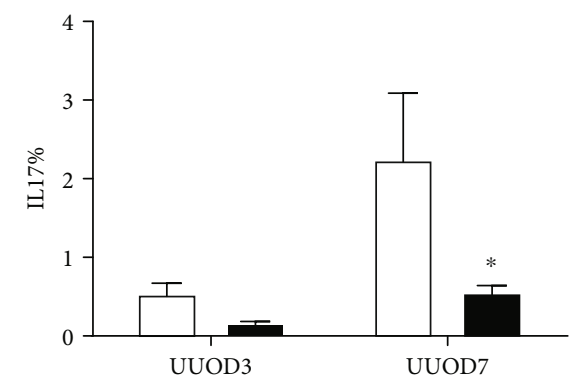

(c)

Figure 4: PMSCs treatment increase Treg and decrease Th17 expression in CD4 ${ }^{+} \mathrm{T}$ cells from PBMC in vitro. (a) CD4 ${ }^{+} \mathrm{T}$ cells were obtained from PBMC of rats at day 3 and 7 after UUO via microbeads, respectively, and cocultured with or without PBMCs. (b) A $0.4 \mu \mathrm{m}$ transwell system was used and activated $\mathrm{CD} 4^{+} \mathrm{T}$ cells were seeded in the lower chamber while PMSCs were seeded in the upper chamber. After 72 hours of incubation, $\mathrm{CD} 4^{+} \mathrm{T}$ cells were stained with CD25-APC and Foxp3-FITC or IL17-APC, CD4-PE, respectively. (c) Histograms representation of the percentage of Treg cells $\left(\mathrm{CD} 25^{+}\right.$Foxp $\left.^{+}\right)$and $\mathrm{IL} 17^{+} \mathrm{CD} 4^{+} \mathrm{T}$ cells in $\mathrm{CD} 4^{+} \mathrm{T}$ cells cocultured with or without PMSC. Error bars are $\pm \mathrm{SD} .{ }^{*} P<0.05$ compared with $\mathrm{CD} 4{ }^{+} \mathrm{T}$ cells group; ${ }^{* *} P<0.01$ compared with $\mathrm{CD} 4^{+} \mathrm{T}$ cells group. $n=4$ in each group. 

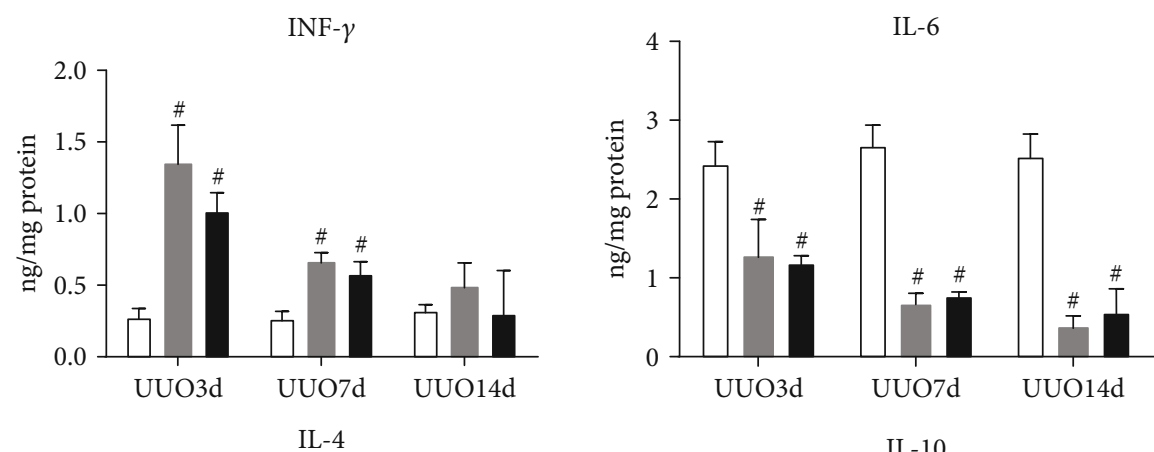

IL-17
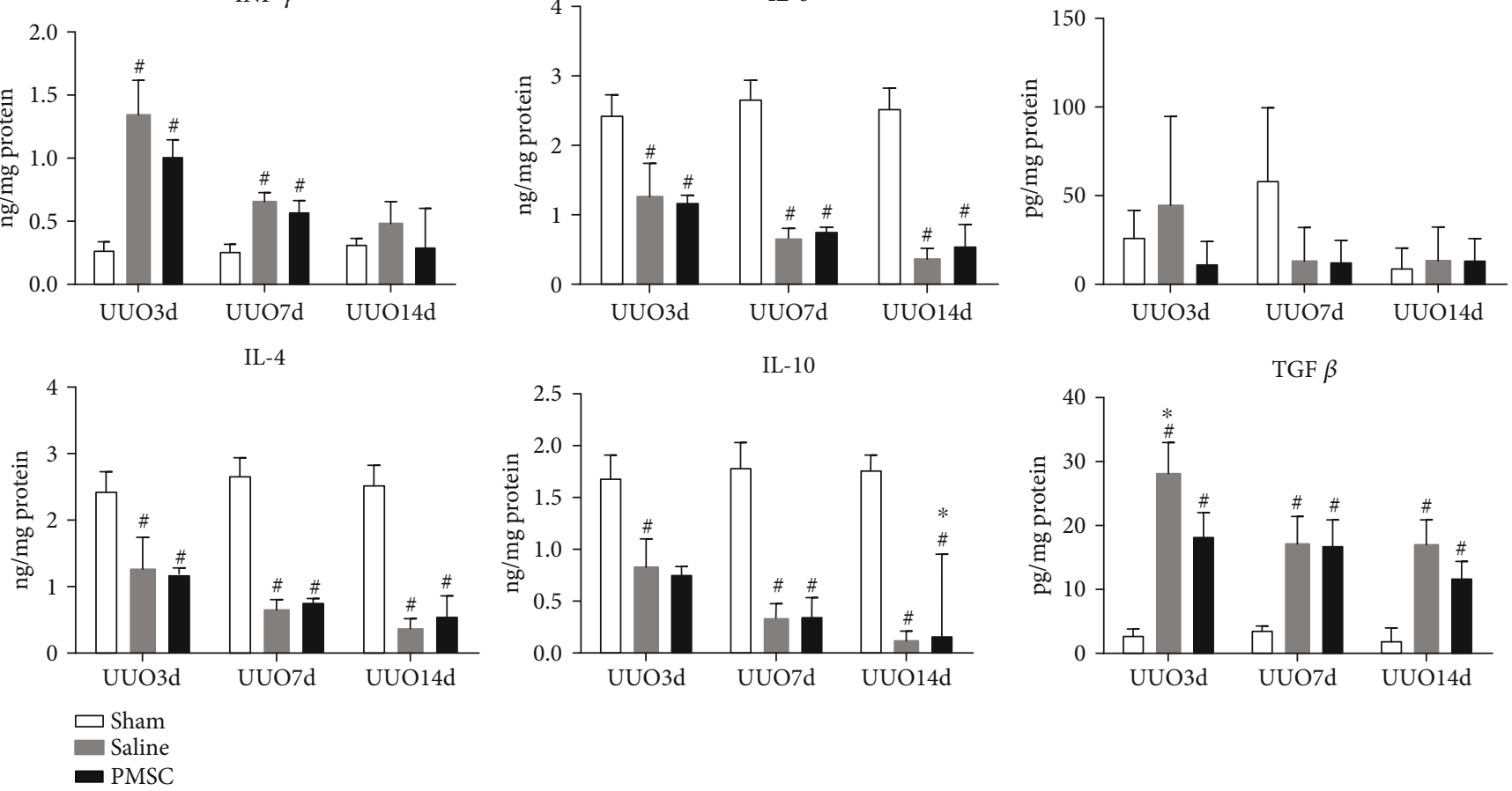

(a)
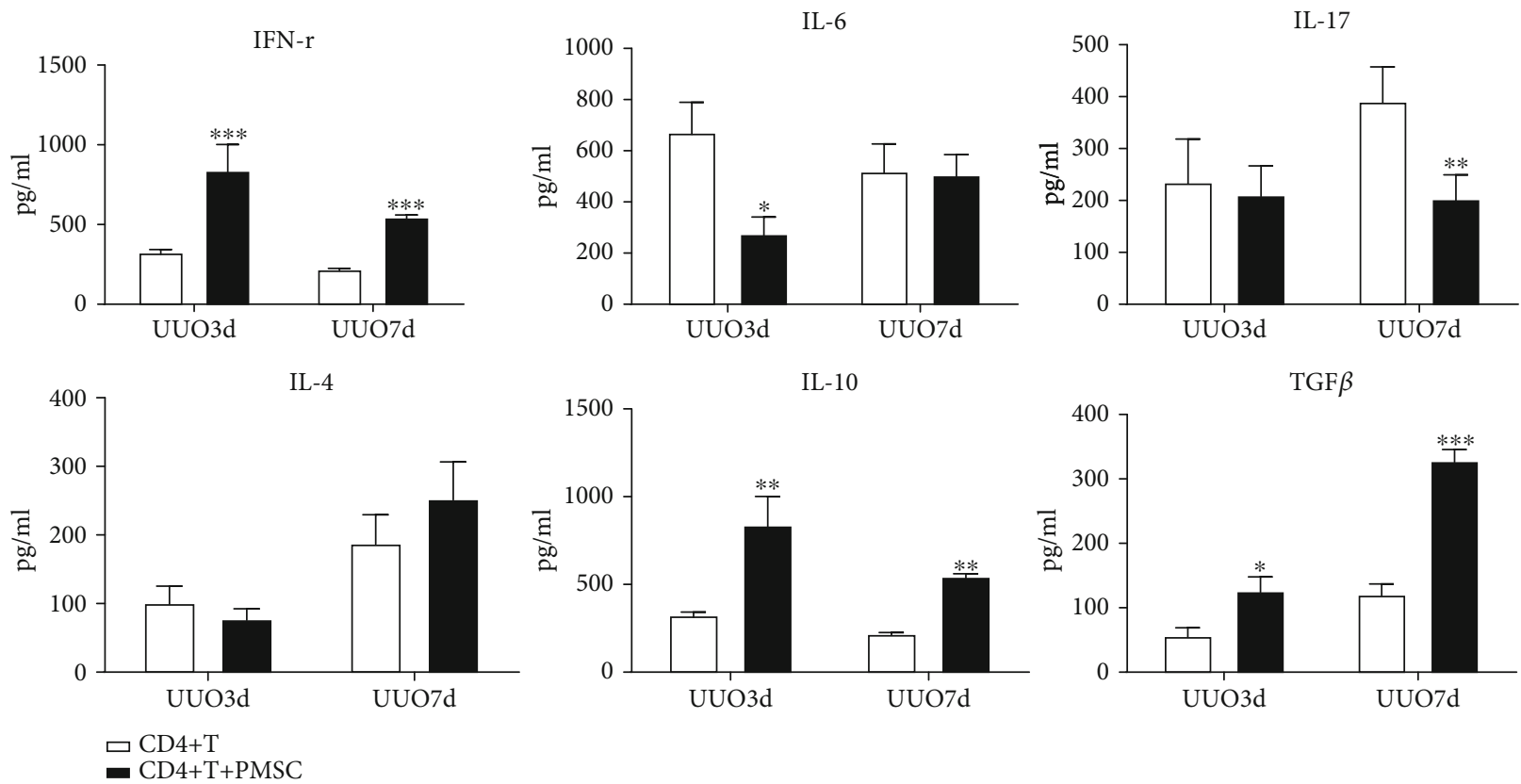

(b)

FIGURE 5: PMSCs regulate the expression of inflammatory cytokines including IFN- $\gamma$, IL-4, IL-6, IL10, IL-17, and TGF- $\beta$ in vivo and vitro. (a) ELISA analysis was performed to detect cytokines expression both from renal tissue homogenate and (b) in vitro experiments. (b) Inflammatory factors tested from cell supernatant of $\mathrm{CD}_{4}^{+} \mathrm{T}$ cells extracted from PMNC of rats at days 3 and 7 after UUO with or without PMSC coculture $(n=4) .{ }^{*} P<0.05$ compared with $\mathrm{CD} 4^{+} \mathrm{T}$ cells group; ${ }^{* *} P<0.01$ compared with $\mathrm{CD} 4^{+} \mathrm{T}$ cells group. ${ }^{* * *} P<0.001$ compared with the $\mathrm{CD} 4^{+} \mathrm{T}$ cells group.

Foxp3 expression in kidney tissue sections from the PMSC intervention group was significantly higher than that in tissue sections from the other groups at 1 or 2 weeks after UUO establishment. These results indicate that PMSCs may relieve tissue injury by increasing the infiltration of Treg cells. T cells that express the transcription factor Foxp3 are a regulatory subset of $\mathrm{CD}^{+}{ }^{+} \mathrm{Th}$ cells, which are necessary for the maintenance of peripheral tolerance and immune homeostasis. 
UUO

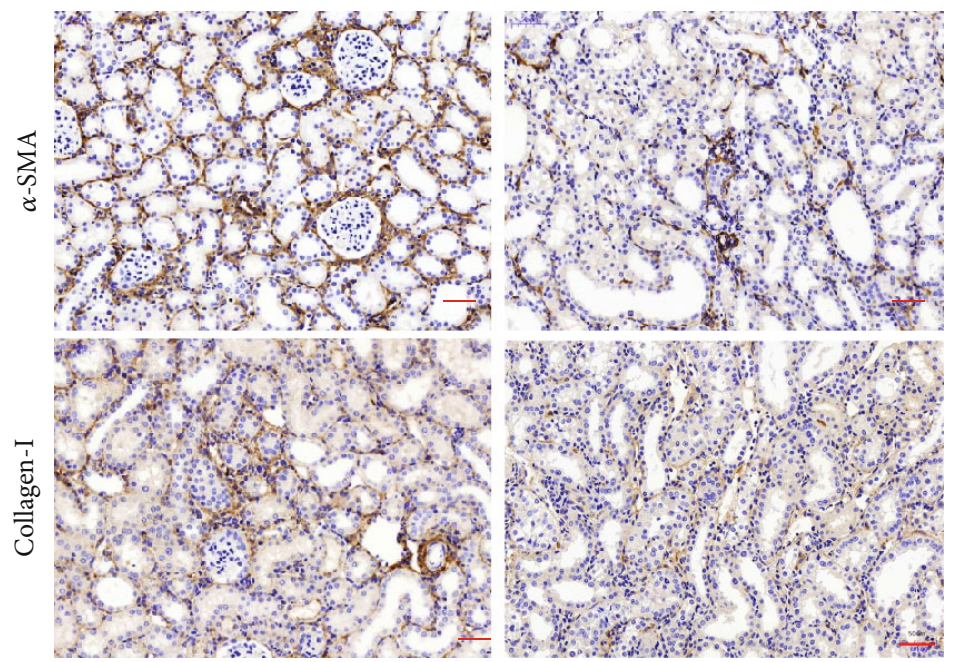

(a)

UUO
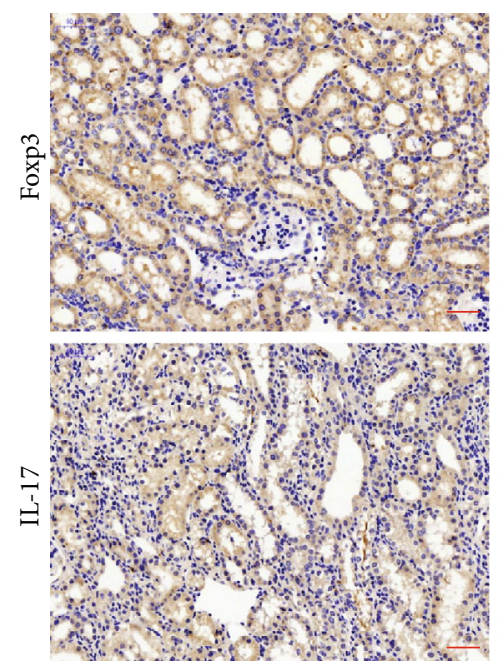

(b)
$\alpha$-SMA

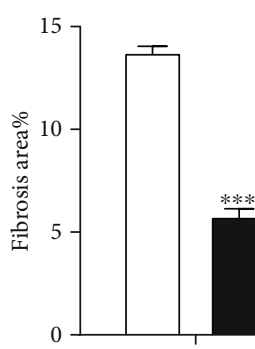

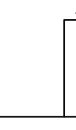

$\square$ UUO

ㄴUUO+EV

UUO+EV
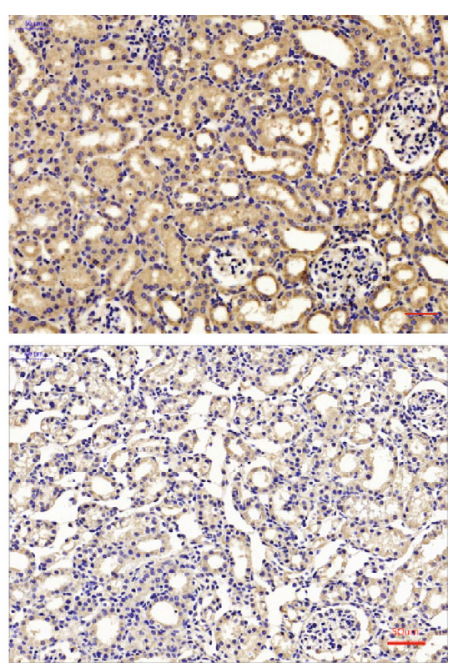

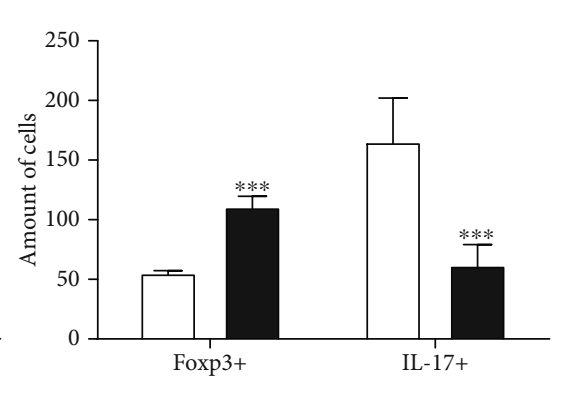

(c)

Figure 6: PMSC-EVs treatment attenuate tubulointerstitial fibrosis and increase Foxp3 expression by downregulating IL17 expression in vivo. (a) IHC for detecting $\alpha$-SMA and COL-I expression in rat renal tissues from the UUO group and UUO+EV treatment group. Scale bar: $50 \mu \mathrm{m}$. (b) IHC for Foxp3 and IL-17 in rat renal tissue sections 7 days after UUO with or without PMSC-EVs treatment. Scale bar: $50 \mu \mathrm{m}$. (c) Fibrosis area and Foxp3 and IL17 positive cells in representative images from (a) and (b) were analyzed by Image J software. Error bars are \pm SD. ${ }^{*} P<0.05$ compared with the UUO group; ${ }^{* *} P<0.01$ compared with the UUO group. ${ }^{* * *} P<0.001$ compared with UUO group. (d) IF for identification of Foxp $3^{+} \mathrm{T}$ cells infiltration in renal tissue after UUO 7 days with or without PMSC-EVs treatment. Scale bar: $50 \mu \mathrm{m}$. (e) Representative IF staining pictures of IL-17 $7^{+}$T cells in the UUO group and UUO+EV group. Scale bar: $50 \mu \mathrm{m}$. 
Recent studies have suggested that Foxp $3^{+}$Treg cells regulate both Th1- and Th17-mediated effector responses [18, 22]. Thus, Foxp $3^{+}$Treg cells may help to suppress pathogenic inflammation.

MSCs exert immunomodulatory effects not only via direct cell-cell contact but also by releasing soluble factors such as IL-10 and TGF $\beta[23,24]$. The varied expression of these factors will lead to differences in regulating immunosuppressive effects. IFN- $\gamma$, which is a Th1 cell-related factor, is a proinflammatory factor and a crucial effector molecule in immunological rejection [25]. In contrast, IL-10 is regarded as a Th2-related anti-inflammatory factor, like IL-4, and plays a key role in the induction of Treg cells [26]. It also recruits Treg cells that are responsible for the regulation of the immune system. In this study, we found that IL-10 could be secreted by PMSCs, which may synergistically relieve inflammatory responses.

After UUO modeling, the expression levels of TGF- $\beta$, IFN- $\gamma$, and IL- 6 were upregulated, while the levels of IL- 4 and IL-10 were downregulated. Fourteen days after the model establishment, the PMSC intervention group showed a higher level of IL-10 than the saline infusion group. These data suggest that PMSCs may influence the conversion of the inflammatory environment into an anti-inflammatory environment by upregulating the expression of the antiinflammatory factor IL-10 and increasing Foxp3 expression locally in renal tissue, which ultimately leads to renal protection.

To further investigate the effects of PMSCs on $\mathrm{CD}^{+} \mathrm{T}$ cells in vitro, we isolated $\mathrm{PB}$ mononuclear cells from UUO rats. PMSCs were cocultured with $\mathrm{CD} 4^{+} \mathrm{T}$ cells from UUO rats. PMSCs increased the proportion of $\mathrm{CD} 4^{+} \mathrm{CD} 25^{+}$Foxp $3^{+}$ Treg cells in the total $\mathrm{CD}^{+} \mathrm{T}$ cell population, whereas the ratio of $\mathrm{IL} 17 \mathrm{~A}^{+} \mathrm{CD} 4^{+} \mathrm{T}$ cells to $\mathrm{CD} 4^{+} \mathrm{T}$ cells was significantly lower in the coculture group than in the purified $\mathrm{CD} 4^{+} \mathrm{T}$ cell group. Luz-Crawford et al. [27] also found that MSCs were able to suppress the proliferation, activation, and differentiation of $\mathrm{CD}^{+} \mathrm{T}$ cells induced to differentiate into Th1 and Th17 cells. We also found that the secretion of antiinflammatory cytokines such as IL-6 and IL-10 was significantly increased in purified $\mathrm{CD}^{+} \mathrm{T}$ cells isolated from UUO rats. However, the secretion of IFN- $\gamma$, which is considered a proinflammatory cytokine, was decreased in the PMSC coculture group, and the expression level of IL-17 was lower in the PMSC coculture group than in the CD $4^{+}$ $\mathrm{T}$ cell group. This study demonstrates that MSCs contribute to the generation of an immunosuppressive environment via the inhibition of proinflammatory $\mathrm{T}$ cells and the induction of $\mathrm{T}$ cells with a regulatory phenotype.

Previous studies have shown that MSCs secrete immunologically active EVs, which can enhance the secretion of antiinflammatory cytokines [28]. MSC-derived EVs enhance Treg production in vitro and in vivo through an antigenpresenting cell- (APC-) mediated pathway by transferring RNA, proteins, and bioactive lipids [13]. In our study, we injected PMSC-EVs that reached the target directly to improve immunoregulatory efficiency. We found that PMSC-EVs had an effect similar to that of MSCs in regulating the Treg/Th17 cell balance in renal tissues after UUO establishment. All the evidence may show that PMSCs regulate immunocytes by changing the subtypes of $\mathrm{CD}^{+} \mathrm{T}$ cells by a paracrine mechanism.

In conclusion, this study reveals that PMSCs and PMSCEVs suppress the proliferation of $\mathrm{CD}^{+} \mathrm{T}$ cells and induce $\mathrm{CD}^{+} \mathrm{T}$ cells to differentiate into Treg and Th2 cells but not Th17 and Th1 cells. PMSCs and PMSC-EVs may convert the inflammatory environment into an anti-inflammatory environment by releasing paracrine factors, which ultimately leads to renal protection under UUO conditions. These findings provide a basic foundation for the future use of EVs as a new biological therapeutic for renal injury or immunological disease.

\section{Data Availability}

The data used to support the findings of this study are available from the corresponding author upon request.

\section{Conflicts of Interest}

All authors declare that they have no conflict of interests.

\section{Authors' Contributions}

Zhu zhu and Chaonan Han contributed equally to this work; both of them are the first author.

\section{Acknowledgments}

This work is supported by Shanghai Pujiang Program (2016PJD032), the Ministry of Education Research Fund for Returned Personnel Research (20050054), the National Natural Science Foundation of China \#31300811 (Yingli Liu), and the Clinical Research of the Ninth People's Hospital, Shanghai Jiaotong University (JYLJ201811).

\section{References}

[1] N. van Panhuys, F. Klauschen, and R. N. Germain, “T-CellReceptor-Dependent Signal Intensity Dominantly Controls $\mathrm{CD}_{4}{ }^{+} \mathrm{T}$ Cell Polarization In Vivo," Immunity, vol. 41, no. 1, pp. 63-74, 2014.

[2] H. Hopfer, J. Holzer, S. Hünemörder et al., "Characterization of the renal $\mathrm{CD}_{4}^{+} \mathrm{T}$-cell response in experimental autoimmune glomerulonephritis," Kidney International, vol. 82, no. 1, pp. 60-71, 2012.

[3] H. J. Paust, A. Ostmann, A. Erhardt et al., "Regulatory T cells control the $\mathrm{Th}_{1}$ immune response in murine crescentic glomerulonephritis," Kidney International, vol. 80, no. 2, pp. 154-164, 2011.

[4] Z. Liu, H. Fan, and S. Jiang, "CD4 ${ }^{+}$T-cell subsets in transplantation," Immunological Reviews, vol. 252, no. 1, pp. 183-191, 2013.

[5] U. Panzer and C. Kurts, "T cell cross-talk with kidney dendritic cells in glomerulonephritis," Journal of Molecular Medicine, vol. 88, no. 1, pp. 19-26, 2010.

[6] N. J. Tubo and M. K. Jenkins, "TCR signal quantity and quality in $\mathrm{CD} 4^{+} \mathrm{T}$ cell differentiation," Trends in Immunology, vol. 35, no. 12 , pp. 591-596, 2014. 
[7] M. Dominici, K. le Blanc, I. Mueller et al., "Minimal criteria for defining multipotent mesenchymal stromal cells. The International Society for Cellular Therapy position statement," Cytotherapy, vol. 8, no. 4, pp. 315-317, 2006.

[8] S. J. McTaggart and K. Atkinson, "Mesenchymal stem cells: Immunobiology and therapeutic potential in kidney disease (Review Article)," Nephrology, vol. 12, no. 1, pp. 44-52, 2007.

[9] S. Choi, M. Park, J. Kim, S. Hwang, S. Park, and Y. Lee, “The Role of Mesenchymal Stem Cells in the Functional Improvement of Chronic Renal Failure," Stem Cells and Development, vol. 18, no. 3, pp. 521-530, 2009.

[10] Y. L. Liu, Y. D. Wang, F. Zhuang et al., "Immunosuppression effects of bone marrow mesenchymal stem cells on renal interstitial injury in rats with unilateral ureteral obstruction," Cellular Immunology, vol. 276, no. 1-2, pp. 144-152, 2012.

[11] Y.-m. Du, Y.-x. Zhuansun, R. Chen, L. Lin, Y. Lin, and J.-g. Li, "Mesenchymal stem cell exosomes promote immunosuppression of regulatory $\mathrm{T}$ cells in asthma," Experimental Cell Research, vol. 363, no. 1, pp. 114-120, 2018.

[12] P. D. Robbins, A. Dorronsoro, and C. N. Booker, "Regulation of chronic inflammatory and immune processes by extracellular vesicles," Journal of Clinical Investigation, vol. 126, no. 4, pp. 1173-1180, 2016.

[13] B. Zhang, R. W. Y. Yeo, R. C. Lai, E. W. K. Sim, K. C. Chin, and S. K. Lim, "Mesenchymal stromal cell exosome-enhanced regulatory T-cell production through an antigen-presenting cellmediated pathway," Cytotherapy, vol. 20, no. 5, pp. 687-696, 2018.

[14] C. B. Portmann-Lanz, A. Schoeberlein, A. Huber et al., "Placental mesenchymal stem cells as potential autologous graft for pre- and perinatal neuroregeneration," American Journal of Obstetrics and Gynecology, vol. 194, no. 3, pp. 664-673, 2006.

[15] S. Ghannam, J. Pène, G. Torcy-Moquet, C. Jorgensen, and H. Yssel, "Mesenchymal Stem Cells Inhibit Human Th17 Cell Differentiation and Function and Induce a T Regulatory Cell Phenotype," The Journal of Immunology, vol. 185, no. 1, pp. 302-312, 2010.

[16] F. Carrión, E. Nova, P. Luz, F. Apablaza, and F. Figueroa, "Opposing effect of mesenchymal stem cells on Th1 and Th17 cell polarization according to the state of $\mathrm{CD} 4^{+} \mathrm{T}$ cell activation," Immunology Letters, vol. 135, no. 1-2, pp. 10-16, 2011.

[17] T. T. Tapmeier, A. Fearn, K. Brown et al., "Pivotal role of $\mathrm{CD}_{4}{ }^{+}$ T cells in renal fibrosis following ureteric obstruction," Kidney International, vol. 78, no. 4, pp. 351-362, 2010.

[18] C. F. Krebs and O. M. Steinmetz, "CD4 ${ }^{+}$T Cell Fate in Glomerulonephritis: A Tale of Th1, Th17, and Novel Treg Subtypes," Mediators of Inflammation, vol. 2016, Article ID 5393894, 9 pages, 2016.

[19] Y. Liu, K. Wang, X. Liang et al., "Complement C3 Produced by Macrophages Promotes Renal Fibrosis via IL-17A Secretion," Frontiers in Immunology, vol. 9, 2018.

[20] L. Liu, P. Kou, Q. Zeng et al., "CD4 ${ }^{+}$T Lymphocytes, Especially Th2 Cells, Contribute to the Progress of Renal Fibrosis," American Journal of Nephrology, vol. 36, no. 4, pp. 386-396, 2012.

[21] R. C. Silva, F. F. Terra, Y. F. Guise et al., "Reduced expression of VAChT increases renal fibrosis," Pathophysiology, vol. 23, no. 3, pp. 229-236, 2016.
[22] L. Ma, H. Zhang, K. Hu et al., "The imbalance between Tregs, Th17 cells and inflammatory cytokines among renal transplant recipients," BMC Immunology, vol. 16, no. 1, 2015.

[23] S. F. H. de Witte, F. Luk, J. M. Sierra Parraga et al., "Immunomodulation By Therapeutic Mesenchymal Stromal Cells (MSC) Is Triggered Through Phagocytosis of MSC By Monocytic Cells," Stem Cells, vol. 36, no. 4, pp. 602-615, 2018.

[24] L. Carreras-Planella, M. Monguió-Tortajada, F. E. Borràs, and M. Franquesa, "Immunomodulatory Effect of MSC on B Cells Is Independent of Secreted Extracellular Vesicles," Frontiers in Immunology, vol. 10, 2019.

[25] K. Minoguchi, N. Yamashita, N. Oda, M. Takeno, H. Kaneoka, and T. Sakane, "Protein Tyrosine Phosphorylation: A Possible Common Signaling Pathway in Human Th1 and Th2 Cell Clones," International Archives of Allergy and Immunology, vol. 118, no. 1, pp. 30-36, 1999.

[26] R. E. Mitchell, M. Hassan, B. R. Burton et al., "IL-4 enhances IL-10 production in Th1 cells: implications for Th1 and Th2 regulation," Scientific Reports, vol. 7, no. 1, article 11315, 2017.

[27] P. Luz-Crawford, M. Kurte, J. Bravo-Alegría et al., "Mesenchymal stem cells generate a $\mathrm{CD} 4^{+} \mathrm{CD} 25^{+}$Foxp $3^{+}$regulatory $\mathrm{T}$ cell population during the differentiation process of Th1 and Th17 cells," Stem Cell Research \& Therapy, vol. 4, no. 3, 2013.

[28] X. Teng, L. Chen, W. Chen, J. Yang, Z. Yang, and Z. Shen, "Mesenchymal Stem Cell-Derived Exosomes Improve the Microenvironment of Infarcted Myocardium Contributing to Angiogenesis and Anti-Inflammation," Cellular Physiology and Biochemistry, vol. 37, no. 6, pp. 2415-2424, 2015. 